\title{
Legal Regulation and Organization of the Work of Management Subjects Related to the Dismissal of Employees of the Penal System of the Russian Federation due to the Loss of Trust
}

\author{
SVETLANA V. ZAVITOVA \\ Vologda Institute of Law and Economics of FSIN Russia, Vologda, Russian \\ Federation \\ ORCID: https://orcid.org/0000-0001-5936-1482, e-mail: zavitova_s@ mail.ru
}

\section{NATALIYA A. MEL'NIKOVA}

Vologda Institute of Law and Economics of FSIN Russia, Vologda, Russian Federation

ORCID: https://orcid.org/0000-0002-3697-4769, e-mail: melnatale@mail.ru

\begin{abstract}
Introduction: thearticleconsiders problematic issues related to thework of management subjects (managers) and attestation commissions in situations when an employee of the penal system of the Russian Federation is dismissed due to the loss of trust. The aim of this study is to identify gaps in the current legislation on the service that arise when a measure of responsibility such as dismissal due to the loss of trust is applied; another aim consists in formulating proposals for improving legislation in this area. Methods: methodological basis of our study is represented by a set of methods of scientific cognition, among which the main place belongs to formal-logical, system-structural, and comparative-legal methods. Results: the study has shown that there are many problematic issues in the law enforcement practice regarding the dismissal of employees due to the loss of trust. The norms of the law do not clearly distinguish the components of corruption offenses for which an employee is subject to dismissal due to the loss of trust or may be brought to another type of liability. The issue regarding the status of the decision of the attestation commission remains unresolved; its decision is of an advisory nature, but at the same time, it is fundamental for making a decision by the employee's superior. There is an ongoing discussion on the composition of the attestation commission; and options for the selection of independent experts are proposed. Discussion: dismissal due to the loss of trust is a specific type of disciplinary penalty, and its implementation is carried out by authorized management entities within the framework of disciplinary proceedings. The procedure for making a decision on the dismissal of employees of the penal system due to the loss of trust needs further improvement in its legal and organizational aspects, taking into account modern law enforcement and judicial practice.

Key word s: corruption offenses; dismissal due to the loss of trust; penal system; disciplinary responsibility; disciplinary penalty; attestation commission.

12.00.11 - Judicial activity, prosecutor's activity, human rights and law enforcement activity.

F or c it ation: Zavitova S.V., Mel'nikova N.A. Legal regulation and organization of the work of management subjects related to the dismissal of employees of the penal system of the Russian Federation due to the loss of trust. Penitentiary Science, 2021, vol. 15, no. 3 (55), pp. 635-641. DOI 10.46741/2686-9764-2021-15-3-635-641.
\end{abstract}

\section{Introduction}

Compliance with the requirements of anticorruption legislation by civil servants is one of the most important tasks of a state body within the framework of the relevant direction of personnel work. Achieving this goal requires taking into account objective and subjective factors. The need to minimize corruption risks in the 
state service by legal means is also pointed out in foreign literature; this fact confirms the relevance of the topic under consideration [19]. At the same time, we believe that bringing a civil servant to legal responsibility is the most effective deterrent measure of influence. For committing corruption offenses, employees can be brought to various types of legal responsibility [7, p. 72], including disciplinary responsibility through dismissal due to the loss of trust. This provision fully applies to employees of the penal system, too.

The institution of dismissal due to the loss of trust was introduced into the legislation relatively recently with the adoption of Federal Law 329-FZ of November 21, 2011 "On amendments to certain legislative acts of the Russian Federation in connection with the improvement of public administration in the field of combating corruption" as a means of combating corruption offenses committed by civil servants in general and correctional officers in particular. The considered type of dismissal involves the inclusion of guilty persons in a special list - the register of persons dismissed due to the loss of trust. Thus, as of August 1, 2021, 2,918 people were included in this register [16].

\section{Discussion}

It is interesting that in legal literature there is an ongoing discussion regarding the nature of the institution of dismissal due to the loss of trust. The first group of scientists believes that dismissal due to the loss of trust is a disciplinary responsibility (for example, I.A. Bagdasaryan, E.V. Davydova, V.M. Koryakin, A.S. Telegin) [3, p. $2 ; 4 ; 17$, p. 101]. These conclusions are based, among other things, on the decisions of the Supreme Court of the Russian Federation [14]. The second group of scientists considers dismissal due to the loss of trust as a specific type of responsibility that relates to disciplinary responsibility only indirectly (for example, V.I. Kuznetsova, Yu.V. Truntsevskii, L.A. Lomakina) $[10$, p. $159 ; 11$, p. 168]. The scientists substantiate this viewpoint on the basis of the specifics of the legislation, since in the legislation, dismissal due to the loss of trust is considered as an independent type of responsibility rather than as one of the types of disciplinary penalties. The third group of scientists considers dismissal due to the loss of trust as an independent type of responsibility and characterizes it as disciplinary-and-official or as official responsibility, since a civil servant acts as a subject of responsibility, which is established by the law on the service (V.K. Aulov, M.B. Dobrobaba, N.A. Kan- drina, Yu.N. Tuganov) [6, p. 199; 8, p. 50; 18, p. 10].

We believe that it would be most reasonable to consider dismissal due to the loss of trust as a specific measure of disciplinary responsibility.

The legislation on the service clearly establishes a list of grounds for which an employee is subject to dismissal due to the loss of trust. Thus, Article 85 of Federal Law 197-FZ of July 19, 2018 (as amended on April 30, 2021) "On the service in the penal system of the Russian Federation and on amendments to the Law of the Russian Federation "On institutions and bodies executing criminal penalties in the form of imprisonment" (hereinafter Law 197-FZ) provides the following grounds for dismissal:

1) the employee's failure to take measures to prevent and (or) resolve a conflict of interests in which they participate as one of the parties;

2) the employee's failure to provide information about their income, expenses, property and property-related obligations, about the income, expenses, property and property-related obligations of their spouse and minor children, or the provision of deliberately unreliable or incomplete information;

3) participation of an employee on a paid basis in the activities of the management body of a commercial organization, except for the cases established by federal law;

4) an employee's engagement in entrepreneurial activity;

5) the entry of an employee into the composition of management bodies;

6) violation by an employee, their spouse and minor children of the prohibition to open and have accounts (deposits), store cash and valuables in foreign banks located outside the territory of the Russian Federation.

Another reason for dismissal due to the loss of trust is the failure of the superior to take measures to resolve the conflict of interests, if they became aware of the emergence of a personal interest of their subordinate, which led or could lead to a conflict of interests.

As follows from the provisions of the legislation, all of these grounds are corruption offenses.

The activity of competent subjects to identify offenses committed in the state service and bring the perpetrators to disciplinary responsibility is an appropriate administrative procedure [13, p. 19]. Thus, according to Law 197-FZ, the procedure for dismissal due to the loss of trust is regulated in Article 53 and is similar to 
the procedure for bringing a person to disciplinary responsibility for committing a corruption offense.

The decision to dismiss an employee due to the loss of trust is made by the head on the basis of a report on the results of an internal inspection conducted by the department for the prevention of corruption and other offenses, which is part of the personnel service of an institution or body of the penal system; and if the report on the results of the inspection was sent to the commission on compliance with the requirements for official conduct of federal civil servants and settlement of conflicts of interest (the attestation commission), then the recommendation of this commission is also taken into account. Thus, we can conclude that there is a duplication of the procedure for bringing a person to responsibility for corruption offenses.

When applying this type of responsibility, managers most often send materials to an attestation commission and make a decision based on its recommendations. We should agree with I.A. Abramov, who believes that appealing to an attestation commission is optimal, since it helps to clarify in more detail the causes, conditions and circumstances of a corruption offense and identify gaps in conducting preventive and information work with public servants. The scientist points out that as a rule, the cause of corruption offenses is legal illiteracy and inattention of employees [1, p. 146].

When applying measures of responsibility to a correctional officer, first of all, it is necessary to pay attention to the terms during which a penalty can be imposed. It should be understood that in this case, the general rule applies, and the violation of the procedural deadlines may be the basis for canceling the decision made [15, p. 15].

Thus, according to Part 5 of Article 53 of Law 197-FZ, the penalty in the form of dismissal due to the loss of trust must be applied no later than six months (while certain periods of time - vacation, business trip, temporary disability, and the period of criminal proceedings - are not included in this time period) from the day when the information about the commission of a corruption offense by an official was received. This day should be considered the day when the person authorized to impose a penalty on the employee receives a report on the results of the inspection. The deadline for bringing an employee to responsibility will be a three-year period from the date of committing this act.
According to the analysis of judicial practice, we see that courts often cancel the decisions of territorial bodies of the penal system on the termination of contracts on the grounds of the loss of trust due to non-compliance with the established deadlines.

Thus, according to the decision of December 6, 2019 no. 2-3318/19, the Leninsky District Court of Rostov-on-Don declared the personnel order no.-I/s dated ... of the Main Directorate of the Federal Penitentiary Service of Russia for the Rostov Oblast on the termination of the contract on the service in the penal system of the Russian Federation and the dismissal of citizen N. according to Paragraph 14 of Part 3 of Article 84 (due to the loss of trust) to be illegal. During the proceedings, it was established that the dismissal of the plaintiff from their post was carried out by an order dated September 5, 2019, during the period of the plaintiff's temporary disability, which became the basis for the cancellation of the dismissal order.

The so-called anti-corruption inspection is an important step in the procedure on dismissal due to the loss of trust. Anti-corruption inspections can be carried out by the units of personnel services for the prevention of corruption and other offenses independently or by sending a request to the federal executive bodies authorized to carry out intelligence-gathering and investigative activities in accordance with Federal Law 144-FZ "On intelligence-gathering activity" dated August 12, 1995. Consequently, the powers of subjects who bring employees of the penal system to liability for corruption offenses (anti-corruption inspection) are broader than those of subjects of a service inspection, since in accordance with Law 197-FZ the service inspection does not provide for the performance of actions beyond the internal activities of the state body.

Personnel departments on combating corruption are an important subject, since they are entrusted with a wide range of duties and functions. If an employee is suspected of having committed a corruption offence, the human resources anti-corruption unit requests the head to schedule an inspection, which should establish or disprove the existence of a corruption offence. Upon completion of the inspection, the employee may be held liable depending on the severity of the corruption offense committed, including dismissal due to the loss of trust.

The peculiarity of conducting an anti-corruption inspection consists in the lack of legislative requirement to obtain an explanation from the 
employee, who committed a corruption offense. We consider it possible to recognize this as a legal and technical flaw on the part of the legislator, because the explanation given by the employee helps to clarify the circumstances of the case, provides the employee with an opportunity to defend themselves by indicating the circumstances that exclude their guilt in the committed act.

According to the analysis of the provisions of Law 197-FZ we see that the legislator did not provide for any factors preventing the dismissal of an employee of the penal system during an official inspection in connection with the termination of an official contract on their own initiative or by agreement of the parties.

Moreover, the legislation does not contain a requirement that the initiated internal inspection should end up with relevant findings and the preparation of an appropriate conclusion. Therefore, in the case of dismissal of an employee of the penal system during the inspection, it is common practice to terminate the proceedings without a legal assessment and qualification of the act as a corruption manifestation, due to the fact that the person against whom the inspection is carried out loses the status of an employee after their dismissal.

Thus, there is a flaw in the anti-corruption legislation that allows an internal inspection to be terminated without a legal assessment of the essence of actions (inaction) that can potentially be regarded as corruption offenses and lead to the loss of trust.

To a certain extent, such an outcome of the inspection is beneficial both for the head of the state body and for the offender, since the reasons for the loss of trust often had to be identified (and could be identified) either at the stage of concluding a contract, or before the emergence of reasons for the current internal inspection. An objective and unbiased qualification of the actions of an employee of the penal system as a person who has lost trust, in any circumstances, automatically raises the question of the competence of the anti-corruption structures of the state body.

It seems that this legal gap contributes to the spread of corruption factors and requires mandatory elimination, since it levels off the latest legislative novelty of Federal Law 273-FZ of August 25, 2008 (as amended on May 26, 2021) "On combating corruption" related to maintaining the register of persons dismissed due to the loss of trust.

Attestation commissions that carry out anticorruption inspection are optional participants in disciplinary proceedings. Attestation commissions are collegial advisory bodies consisting of various specialists and independent members.

The powers of attestation commissions in bringing employees of the penal system to responsibility are established by the Decree of the President of the Russian Federation no. 821 of July 1, 2010 (as amended on September 19, 2017) "On commissions for compliance with the requirements for official conduct of federal civil servants and the settlement of conflicts of interest". The head of the state body, on their own initiative, has the right to send a report on the results of the anti-corruption commission to attestation commissions.

It should be noted that these commissions do not have state powers. Some authors point out that, on the one hand, these are public bodies that implement anti-corruption measures taken by the heads of state bodies [9, p. 52]. On the other hand, they perform advisory and consulting functions. Within the framework of their activities, management decisions are developed in the field of combating corruption for the head of a state body.

Researchers express concerns about the performance efficiency of such commissions due to the fact that they are intradepartmental; it is suggested that the commissions on compliance with the requirements for the official conduct of civil servants and the settlement of conflicts of interest should be given a non-departmental status [12, p. 133].

Attestation commissions are formed by adopting the relevant legal act by a state body. This document approves the composition of the commission and the procedure for its work. The Central Office of the Federal Penitentiary Service of Russia has an attestation commission of the Federal Penitentiary Service for compliance with the requirements for the official conduct of employees of the penal system and the settlement of conflicts of interest (Order of the Federal Penitentiary Service of Russia no. 1040 dated December 9, 2016 (as amended on July $19,2018)$ ). Similar commissions are created in each territorial body of the department.

Scientific research shows that members of attestation commissions, which are representatives of scientific and educational institutions, are not always specialists in public service issues in general and anti-corruption measures in particular [12, p. 138]. Thus, when assessing their professional specialization and its compliance with the profile of the activity of the attes- 
tation commission, the following aspects were taken into account: the topics of the training courses, the topics of scientific publications, and the information about the sphere of professional interests and additional professional education. Of course, we should not ignore the fact that determining the specialization of representatives of scientific and educational institutions is a difficult task. This is explained by the fact that in some cases, the relevant information about such representatives is either absent at all, or does not help to establish the scope of their professional activity [2, p.61]. According to the results of research conducted by individual scientists, in 34 commissions out of 68 (that is, in half of the cases) there is at least one representative of a scientific or educational organization whose professional activity is public service or anti-corruption issues [12, p.140].

It is noteworthy that there are many questions about the independence of external representatives who are members of the commission. For example, there is no mechanism for selecting these representatives, there are no guarantees of independence and responsibility of commission members, as well as decent pay for their work. Some authors note that the heads of state bodies invite loyal and familiar experts in order to ensure the adoption of desirable decisions. Naturally, this situation negatively affects the efficiency of the commission, as well as the performance of significant functions [5, p. 36].

It seems that in order to improve the performance of attestation commissions, it is necessary to conclude cooperation agreements with scientific and educational institutions. Within the framework of this agreement, the issue of determining a candidate for performing the duties of a member of the attestation commission will be assigned to the jurisdiction of a scientific or educational institution. A scientific or educational institution will be able to choose the most suitable candidate on the basis of the topics of the training courses the candidate teaches, the topics of their scientific publications, and the information about the field of their professional interests and additional professional education.

In general, describing the status of attestation commissions, we should point out that their powers in the procedure of dismissal sue to the loss of trust are quite significant. Attestation commissions, in the course of discussions, can reliably establish the existence of an event and the composition of a corruption offense, and determine the optimal measure of responsibil- ity for an employee of the penal system who committed a corruption offense.

Management entities that decide on the dismissal of an employee due to the loss of trust for a corruption offense may be guided by the following procedural documents:

1) recommendations of the attestation commission;

2) the report on the results of the anti-corruption inspection.

For the management entity, these two documents serve as recommendations; this fact not only reduces their significance, but also introduces uncertainty into the procedure itself. The very possibility of choosing the source document so as the head could make the final decision is a corruption factor; therefore, it is necessary to recognize these documents as mandatory within the framework of the procedure under consideration.

At the same time, as we can see from the analysis of judicial practice, the leadership of the territorial bodies of the Federal Penitentiary Service of Russia not always makes a decision to dismiss an employee due to the loss of trust, when considering issues related to the resolution of conflicts of interest, the failure to provide the information or the provision of false information about income (expenses), property and property obligations for themselves or their family members.

The difficulty lies in the fact that the legislation does not contain a clear distinction between the cases when a dismissal due to the loss of trust should be applied, and when it is allowed to apply other penalties provided for in Article 50 of Law 197-FZ.

Thus, according to the analysis of the Decision of the Judicial Board for Civil Cases under the Supreme Court of the Russian Federation dated July 27, 2020 no. 21-KGPR20-2-K5, it follows that by the Order of the Federal Penitentiary Service of Russia for the Kabardino-Balkar Republic dated November 21, 2018 no. 299-k, citizen $A$. received a service incompetence note for non-compliance with the requirements of Part 2 of Article 11 of Federal Law 273-FZ of November 25, 2008 "On combating corruption" on the basis of a decision of the attestation commission, which established the fact of non-compliance with the requirements for official conduct and (or) requirements for resolving conflicts of interest, namely, the fact that citizen A. did not inform the leadership of the Federal Penitentiary Service of Russia in the KabardinoBalkar Republic that his relatives (cousins) were 
serving in the Federal Penitentiary Service of Russia in the Kabardino-Balkar Republic.

As follows from the materials of the case, according to the results of the inspection of the Federal Penitentiary Service of Russia, it was ordered to declare the decision of the attestation commission of the Federal Penitentiary Service of Russia for the Kabardino-Balkar Republic, registered in the protocol of November 16, 2018, regarding the recommendations on the application of legal liability measures against citizen $A$. in the form of a warning about his service incompetence, cancel the Order of the Federal Penitentiary Service of Russia for the Kabardino-Balkar Republic of November 21,2018 no. 299-k on imposing on citizen A. the penalty for a corruption offense in the form of a warning about his service incompetence, submit to the personnel department of the Federal Penitentiary Service of Russia materials for the dismissal of citizen $A$. from the service due to the loss of trust.

\section{Results}

Thus, the procedure of dismissal of employees of the penal system in connection with the loss of trust is a kind of disciplinary procedure and has its own specific features. In such cas- es, heads, personnel departments (mandatory management subjects) and attestation commissions (optional management subjects) act as the subjects of managerial decision-making.

In order to improve the procedure under consideration, it is necessary to exclude corruption-causing factors when making managerial decisions. To do this, it is necessary to make changes and additions to the relevant provisions of Law 197-FZ, in particular, to include in this law the obligation of the person who committed the offense to give explanations on the essence of the act; to exclude the possibility of termination of the service contract on the initiative of the employee or by agreement of the parties during the internal inspection; to provide for the mandatory completion of the initiated internal inspection with conclusions and preparation of an opinion; the report on the results of the anti-corruption inspection and the decision of the attestation commission should be recognized as mandatory; the issue of determining a candidate for performing the duties of a member of the attestation commission should be attributed to the jurisdiction of a scientific or educational institution within the framework of a cooperation agreement.

\section{REFERENCES}

1. Abramov I.A. On the issue of legal regulation of disciplinary responsibility of state civil servants. Gumanitarnye, sotsial'noekonomicheskie i obshchestvennye nauki=Humanities, Socio-Economic and Social Sciences, 2015, no. 2, pp. $145-147$. (In Russ.).

2. Alimpiev S.A. On some topical issues related to the activity of commissions on compliance with the requirements for official conduct of civil servants and settlement of conflicts of interest. Vestnik Ural'skogo yuridicheskogo instituta MVD Rossii=Bulletin of the Ural Law Institute of the Ministry of Internal Affairs of Russia, 2017, no. 4, pp. 60-63. (In Russ.).

3. Bagdasaryan I.A., Koryakin V.M. On some legal implications of the dismissal of military personnel and civilian personnel in connection with the loss of trust. Pravo v Vooruzhennykh Silakh=Law in the Armed Forces, 2017, no. 9, pp. 2-6. (In Russ.). 4. Davydova E.V. Specifics of dismissal of a civil servant. Otdel kadrovgosudarstvennogo (munitsipal'nogo) uchrezhdeniya= Personnel Department of a State (Municipal) Institution, 2020, no. 9. Retrieved from the reference and legal system "Konsul'tantPlyus".

5. Deitseva N.A., Martynov A.V. Administrative and legal regulation of the activities of the Commission on observance of requirements to official conduct of civil servants and to the settlement of conflicting interests. Administrativnoe $i$ munitsipal'noe pravo=Administrative and Municipal Law, 2010, no. 7, pp. 35-38. (In Russ.).

6. Dobrobaba M.B. Conceptual framework of service-tort law. Lex Russica, 2014, no. 2, pp. 199-210. (In Russ.).

7. Zhitkov A.A. Development of criminal legislation in the field of combating corruption. In: Nekrasov V.N. (Ed.). Aktual'nye voprosy naznacheniya i ispolneniya ugolovnykh nakazanii: sbornik nauchnykh trudov []. Vologda: VIPE FSIN Rossii, 2017. Pp. 72-77. (In Russ.).

8. Kandrina N.A. On the issue of official responsibility of state civil servants. Rossiiskaya yustitsiya=Russian Justice, 2015, no. 3, pp. 50-53. (In Russ.).

9. Nozdrachev A.F. (Ed.). Konflikt interesov na gosudarstvennoi i munitsipal'noi sluzhbe, v deyatel'nosti organizatsii: prichiny, predotvrashchenie, uregulirovanie: nauchno-prakticheskoe posobie [Conflict of interests in the state and municipal service, in the activities of organizations: causes, prevention, settlement: a scientific and practical guide]. Moscow: INFRA-M, 2016. 224 p.

10. Kuznetsov V.I., Truntsevskii Yu.V., Lomakina L.A. Dismissal of civil servants due to loss of trust: problems of theory and practice. Zhurnal rossiiskogo prava=Journal of Russian Law, 2020, no. 1, pp. 159-169. (In Russ.).

11. Lomakina L.A. Some problems of dismissal of the public civil servants for loss of trust. Zhurnal rossiiskogo prava=Journal of Russian Law, 2019, no. 12, pp. 198-173. (In Russ.).

12. Maskaleva O.S. Commissions on compliance with requirements to official conduct and resolution of conflicts of interests: formal requirements and actual composition. Gosudarstvennoe upravlenie. Elektronnyi vestnik=Public Administration. E-Journal, 2016, no. 59, pp. 131-163. (In Russ.).

13. Nagornykh R.V. Administrative and legal procedures in the mechanism of public service in the law enforcement sphere. Vestnik Grodnenskogo gosudarstvennogo universiteta imeni Yanki Kupaly. Seriya 4. Pravovedenie=Vesnik of Yanka Kupala State University of Grodno. Series 4. Jurisprudence, 2019, vol. 9, no. 2, pp. 17-25. (In Russ.). 
14. Review of the 2012-2013 practice on consideration of the cases on disputes related to bringing state and municipal employees to disciplinary responsibility for committing corruption offenses. Byulleten' trudovogo i sotsial'nogo zakonodatel'stva Rossiiskoi Federatsii= Bulletin of Labor and Social Legislation of the Russian Federation, 2014, no. 9, pp. 219-231. (In Russ).

15. Popova A. Dismissal on distrust. Trudovoe pravo= Labor Law, 2019, no. 11, pp. 15-19. (In Russ.).

16. The register of persons dismissed due to the loss of trust. Official website. Civil service. Available at: https://gossluzhba. gov.ru/reestr (accessed August 10, 2021). (In Russ.).

17. Telegin A.S. Disciplinary responsibility of state civil servants. In: Pyatyi Permskii kongress uchenykh-yuristov ( $g$. Perm', 24-25 oktyabrya 2014 g.): izbrannye materialy [The Fifth Perm Congress of Legal Scientists (Perm, October 24-25, 2014): selected materials]. Moscow: Statut, 2015. Pp. 101-110. (In Russ.).

18. Tuganov Yu.N., Aulov V.K. Register of persons who have lost trust: problems of formation. Pravo v Vooruzhennykh Silakh=Law in the Armed Forces, 2018, no. 3, pp. 10-13. (In Russ.).

19. Sharma S.K., Sengupta A., Panja S.C., Nandi T. Corruption risk assessment methods: a review and future direction for organizations. ELK Asia Pacific Journal of Finance and Risk Management, 2016, vol. 7, iss. 4, pp. 1-44.

\section{INFORMATION ABOUT THE AUTHORS}

SVETLANA V. ZAVITOVA - Candidate of Sciences (Law), Associate Professor, head of the Department of AdministrativeLegal Disciplines, Faculty of Law, Vologda Institute of Law and Economics of FSIN Russia, Vologda, Russian Federation. ORCID: https://orcid.org/0000-0001-5936-1482, e-mail: zavitova_s@ mail.ru

NATALIYA A. MEL'NIKOVA - Candidate of Sciences (Law), Associate Professor, associate professor of the Department of Administrative-Legal Disciplines, Faculty of Law, Vologda Institute of Law and Economics of FSIN Russia, Vologda Institute of Law and Economics of FSIN Russia, Vologda, Russian Federation. ORCID: https://orcid.org/0000-0002-3697-4769, e-mail: melnatale@mail.ru 